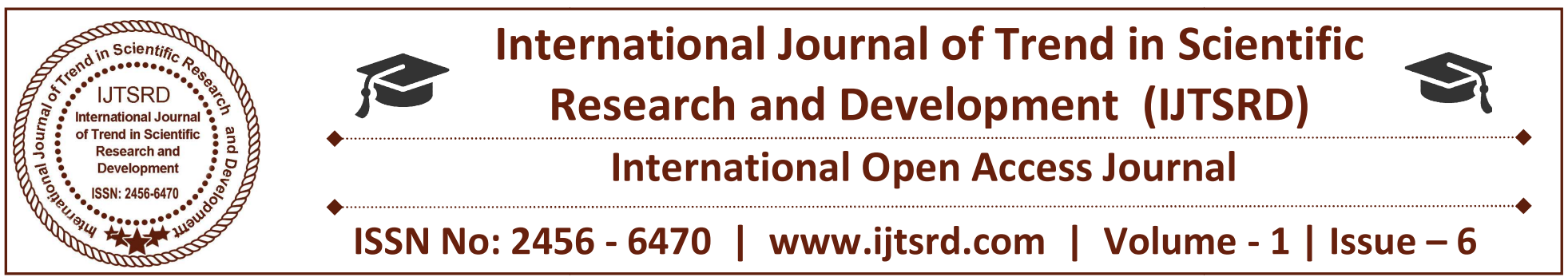

\title{
How does Terrorism Effect on Business and Relation Between Countries
}

\author{
Prof. Sidharth S. Raju \\ Assistant Professor \\ Academy of Hotel Management \& Catering Technology, Dehradun, Uttarakhan
}

\section{ABSTRACT}

The international business or IB is threatened by the indirect and direct effects of terrorism. Since the moment governments have tightened the safety of public sites, the various businesses have turned into exponential attractive targets for terrorist attacks, with vital implications for the performance and operations of the companies that are multinational in nature. Though, substantial studies have been done in different fields about terrorism, less scholarly research has been done on the various challenges which it inflicts upon international business as well as how to address terrorism as a problem. Through this particular article we would conceptualize the terrorism concerned with international business. The background on effects and dimensions of terrorism as well as developing theoretical grounding for researching terrorism by sketching on literature provided by international business, political science, economics and different sectors; shall be provided by us. Once discussion on findings from review of the literature is done, a comprehensive program for subsequent research concerning the connection between international business and terrorism is offered by us. The program that we offer emphasizes on the effects of organizational preparedness, terrorism, company performance and its strategy, global distribution and global supply channels, as well as the issues pertaining human resource. The review that we render, aid in establishing a baseline that further assists in empirical research in the future. This consistent with research in an early stage, international business scholars get encouragement to offer perspectives as well as effective solution that are useful and throw required light on the various aspects of terrorism and also aid in reducing its devastating effects for multinational firms and international business.

Keywords: Terrorism, International Business (IB)

\section{INTRODUCTION}

From early 1980s, the effects of terrorism have evidently become increasingly lethal and complex [1]. Widely speaking, the three trends which are interrelated have altered terrorism's nature in a significant manner.

1. Globalization of information transfer, travel and commerce that facilitates the capacity of far-away but same-objective collaborators, increases ideological competition and economic disparities salience to undertake activities that are harmful;

2. Increase in religious fundamentalism as well as its militant exercise, specifically in the Islamic nations;

3. Weapon availability that could result in mass annihilation (including biological, chemical and nuclear weapons), rendering small groups, and/or individuals in possession of extremely limited assets, with asymmetrical, lethal power [2]. 
Terrorism's direct effects are primarily characterized by lives lost along with destruction of equipment, building and infrastructure. Though, only few businesses have to suffer such effects by terrorism. In contrast to the direct effects, the indirect effects are widely felt by many because of terrorism. Such indirect effects include buyer demand declines, an increased transaction cost in international businesses, chain of international supply being interrupted, and foreign direct investment being declines while new government procedures and regulations intended to curb emergent threats posed from terrorism [3].

Friction or transaction costs related to terrorism could significantly affect the international business [4]. To cite an example, the chain of international supply interruptions that follow the attack on United States of America on September 11, 2001 led auto giant Ford to close 5 of its auto plants in US; temporarily [5]. Federal Express, the renowned global firm for express delivery lost more than $\$ 100$ million in the first 48 hours from 9/11 attacks on the towers [6]. The scholars have discovered a powerful connection between international investment decline and terrorism [7]. If an example is to be cited, it has been analyzed by Drakos (2004) by observing 23 Latin American nations from a period of 1969 to 1988 that terrorism significantly made a negative impact on the economic development and inward investment [8].

New impediments are produced by terrorism to crosscountry investment and trade, as country and supercountry governments tend to impose anti-terrorism regulations, procedures and policies [9]. Responses like that have the capacity to have the commercial environment alter in manners that are more harmful for economic interests of a business that the events of terrorism that have provoked them [10]. To cite an example, the increased volume of inspections of the shipping containers as well as fresh security plans to have the ports protected have consequently decreased the international logistics and shipping efficiency [11]. From 2003, when United States of America enforced "24-hour rule", which dictates that sea carriers must render US Customs Service the descriptions in details of the sea container's content that is to reach United States of America 24 hours prior to loading the container on a vessel and no less, at a seaport on foreign soil. Listing of all contents have to be extremely specific and in order. Failing to comply such rule will render no permission for the vessel carrying such cargo to be allowed for docking at any US port as consequence [12]. As per the United
States Trade Representative of 2006, delays in new shipping are considered to be same to a $2.4 \%$ tariff rate that is similar to every protective tariff that Japan imposes.

The resources of private parties, military and government are consumed by terrorism, which are meant to be expended to guard and prevent against the attack. As per example, we can see that from the year 2001 all through 2005, the United States military spending increased by close to $\$ 100$ billion in order to fund "war on terrorism", which is an additional amount when the expenses on Iraq and Afghanistan conflicts are already high [13]. Search procedures for airport utilized by Transportation Security Administration of US costs nearly $\$ 5$ billion per annum [14]. The subsidies provided by government to fire and police departments for the preparedness against terrorism attacks cost a lot of money that go up to billion dollars every year [15]. Companies tend to incur extra billion each year to manage the risks that are terrorism-induced, and to be in compliance with government procedures and regulations intended to have the terrorism thwarted [16].

To assess the managerial concerns, annual reports of the Fortune 500 firms were reviewed by us that belonged to a period of 2003 - 2006, and we found "terrorism" mentioned 1141 times, which is an average of far than any mention in other reports produced annually. Tendency of mentioning terrorism has increased during this period in numerous key sectors of business. As per survey of Enders, Walter and Todd (2006) that connected with 61,600 people chosen randomly across 60 nations, "war on terrorism" has been chosen as fourth vital priority among the 13 choices that world leaders must work towards which were followed by "elimination of poverty", "growth of economy", and "avoiding wars" [17].

The scholars have confirmed terrorism as vital policy issue internationally [18], while it is also one amongst the critical international business problems at the front [19]. It is noted by Kunreuther et al (2003) that as an ultimate type of anti-globalization, terrorism is constantly on a rise [20]. When we went through the ABI/Inform library database from 1986 - 2008 periods in the scholarly journals, we discovered 1381 articles with "terrorist", "terrorism", or "terror" word in the title of the article, which belonged to the fields of political science and economics. Journal of International Business Studies had just one article in 
2009 , focused on the terrorism, which was the seminal study of Harvey's (1993) on the approaches of corporate tactics. If described in brief, few exceptions are present [21], little research has been done in connection with international business and terrorism.

The main objective with this article is to advance the scholarship in the area of terrorism. Conceptualizing terrorism connection to international business; we would render comprehensive review of the relevant, extant literature to give background for apt scholarship; as well as offer a thorough plan for research in future on the connection between international business and terrorism. We would draw from international business, political science and economics the precise literature, to render framework on terrorism and its various aspects. The reviews that we give, aid in establishing baseline for empirical research in the future on international business and terrorism, as well as to discover the results which advice on pockets where scholars of international business may concentrate their efforts made on research. Review of literature renders theoretical grounding that may be used in laying the research foundation for the future. Thereafter discussing results from the review of literature, we suggest a complete plan for research in future, in connection with relationship between international business and terrorism.

\section{A. Background on Terrorism}

In order to achieve religious, ideological or political objective; the sub-national groups attempt to intimidate large number of audience by use of premeditated and systematic threat or violence. Such a practice involves communicating an ideological, religious or political message through coercion, intimidation or fear of general populace or noncombatant populace [22]. Objective of terrorism is to have the target populace be influenced and have its behavior affected in manners that will serve the terrorist's.

Overpassing the national borders is a dimension that is added by international terrorism. Terrorism's international dimension emphasizes on actions that appear from "foreign alliance of the perpetrators, its human or institutional victim's nature, the aim of their demands, or its logistical executions" [23]. Moreover, planned acts in one nation and carried out in different nations are deemed as terrorism of international gravity.

\begin{tabular}{lll}
\hline Event & Date & Victims \\
\hline Attack on Israeli athletes at the Olympic Games & 5 September 1972 & 11 killed \\
Attacks on US and French military personnel, Lebanon & 23 October 1983 & 305 killed, 75 injured \\
Airliner bombing over Lockerbie, Scotland & 21 December 1988 & 270 killed \\
World Trade Center, New York & 26 February 1993 & 6 killed, 1042 injured \\
Sarin gas attack, subway, Tokyo & 20 March 1995 & 12 killed, 1034 injured \\
Subway system, Paris & 25 July 1995 & 8 killed, 80 injured \\
Central Bank, Colombo, Sri Lanka & 31 January 1996 & 91 killed, 1400 injured \\
US embassy, Nairobi, Kenya & 7 August 1998 & 213 killed, about 4000 injured \\
World Trade Center, New York & 11 September 2001 & 2992 killed, numerous injured \\
Nightclub, Bali, Indonesia & 12 October 2002 & 202 killed, 209 injured \\
Ferry system, Philippines & 27 February 2004 & 116 killed, numerous injured \\
Commuter trains and stations, Madrid & 11 March 2004 & 191 killed, 2050 injured \\
Subway system, London & 7 July 2005 & 56 killed, about 700 injured \\
Marriott Hotel, Islamabad, Pakistan & 20 September 2008 & 53 killed, about 250 injured \\
Various hotels and facilities, Mumbai, India & $26-29$ November 2008 & 173 killed, about 308 injured \\
\hline
\end{tabular}

Table 1: Major terrorist event

The above Table 1 has a list of recent attacks made by terrorists that brought substantial destruction and casualties. Such events are certainly noteworthy since they imposed much destruction and harm, while them typically striked at locations that were important to nations and firms, like public transportation, tourist destinations, military installations, and prime business facilities. Recent years saw injury or even death from such attacks as an increased probability. More lethality has resulted partly from a rise in suicide attacks that became more common towards 1990s as observed. Globally, 53 suicide attacks were carried out in 2001 which also included the 9/11 attack, while it peaked to 300 in the year 2005, where Iraq accounted for half of those attacks as [24] observed. With Iraq war receding, the suicide attacks also went down. However, they will likely remain pretty popular as an attack tactic, for other than their capacity to kill many at once; they also inflict prominent psychological harm as well as additional 
indirect effects that have business implications. In the Christmas of 2009, when Al-Qaeda inspired suicide bombing in one of the commercial aircrafts over Detroit, Michigan skies failed, it averted many lives being lost; both in the flight as well as on ground below the flight.

\section{B. The New Terrorism}

Major part of 20th century saw terrorism motivated primarily by separatism, nationalism, inequality on socio-economic front, and Marxist ideologies [25]. However, in 1980s, fresh reasons emerged which differentiated the contemporary terrorism that defined it as new terrorism from its previous kinds. One of its new elements were that the new terrorism became more violent in comparison to its previous types. The new terrorists displayed a readiness to mount attacks which would inflict massive life loss and damage [26]. The examples of 9/11 attack; Mumbai, India attack; and train bombing in Madrid can be taken for the same. Additionally, the new terrorists have a tendency of low or no discrimination for their chosen target, while they more often conduct their violent activities towards the "soft targets", like business facilities, mass transit and hotels [27].

Sometimes, the terrorist networks adopt the metanational organization's characteristics which have the potential to source centrally and teach locally [28]. Analyses with time-series of attacks made by terrorists track the international network's rise [29]. With time, these networks brought experience and resources to take out new targets, which consequently resulted in massive damage to property and life. Considering the organic and enigmatic nature of recent groups of terrorists, it becomes extremely difficult, when not impossible, to predict their targets by international companies and estimate danger [30].

\section{Specific Effects of Terrorism}

Various markets' globalization has coincided with dangers of globalization [31]. The technologies for advanced communication, and the trade, finance, and investment liberalization, have magnified the spots where illicit activities may flourish beyond the control of government [32]. Similar to how openness caters to stimulate individual firms and national economies, they become vulnerable because of it to all external strengths [1]. Living stands rise and consumption opportunities gets promoted by free trade, but they facilitates activities of various entities which threaten security and safety.
In this particular context and within it, scholars did conceptualize terrorism's impact on the performance and actions of international companies. The evidence from practitioners, government and anecdotal sources indicates terrorism to be among the highest concerns of national governments and MNEs [2]. Different surveys signify that few companies have raised security budgets so to defend themselves against any probable threats that could be generated by terrorism [4]. Many companies appear to have terrorism included in decision-making when selecting international markets, along with finding and managing the operations on foreign territory [8].

Though, clues indicate that majority of companies fail to adequately prepare for the terrorist attacks [10]. An example would be apt here, when few US or British companies have their business continuity schedule in order [12]. Numerous companies were surveyed in the research that we carried out, regarding the perception that they have of terrorism as well as their responses to the same. Results advice that firms tend to be concerned about the act of terrorism and the implications it may bring upon their activities of business. Generous number of companies in the research that we carried out, experienced an increased business costs, interruptions, shifts of international business, its supply chains globally as well as other international business challenges that are terrorism related. Few firms take in consider the possibility of terrorism when planning operations for international business. Generally, majority of companies that were surveyed by us failed to engage in advance preparation or sufficient planning that is terrorism connected. The smaller companies which were active in international business were unlikely considering or planning for safety strategies against terrorism in any of the activities that they carried out internationally.

The buyer demand declines have happened because of the panic and fear that ensued following acts of terror [15]. Example could be of $9 / 11$ attack that precipitated a wide response psychologically, which led in massive decline in the buyer behaviour for the industrial as well as consumer goods or commodities. The increased transactions cost in international business that incur since the companies make efforts to both comply with their government mandates and defend themselves against terrorism; where the former is intended for improving the commercial activities in a secured environment [20]. The costs that are connected with the increase in efforts of company 
security affect internationalizing company's competitiveness [22].

Interference in the supply chains of international operations because of terrorism turns into delays or shortages of vital dossier [14]. The interference reduces logistics and supply chain efficiency [8]. The procedures, regulations and policies made by government to tackle terrorism mostly alter the environment for business as well as change the global commerce's ease in carrying out their activities. The FDI declines could be the consequence of terrorist activities. There is ample evidence in the literature that higher rates of domestic terrorism tend to have the capital inflow reduced in specific fields [6]. It has been noticed in Latin America, Israel, Greece, and Spain [3].

Countries have picked up many initiatives to have the security improved in their key systems, specifically in the framework of international logistics, transportation, information technology, and communication. An example could be of United States that needs companies to submit merchandise's manifests on both exports and imports. Fresh measures like Patriot Act, International Ship and Port Facility Security Code, Maritime Transportation Security Act, and Container Security Initiative have directly imposed billions in the compliance as well as other costs across the private sector companies [17]. Fresh security and regulations efforts have affected the international company's competitiveness [18], partially by business transactions costs increase [25]. An example can be cited of the continuity insurance cost of business increasing substantially since the 9/11 [26]. New security procedures and regulations cost exceeds the advantages that are provided by them [27].

A framework has been devised by Li (2005) which portrays hierarchy of terrorism's impact. Such a hierarchy displays terrorism according to its primary effects (e.g.; on particular industries), secondary effects (e.g.; on intelligence, security and investments), response-generated effects (e.g.; on global oil prices, growth rates and supply chains), and longstanding matters (e.g.; on the significance of various freedoms, geopolitical alliances, and the State) [21].

Terrorism mainly has an impact on such global industries as aviation, insurance, finance, travel, transportation, and tourism [27]. Tourism produces plentiful foreign exchange, and is important to both the grown and growing economies. Tourism is a "soft target", and a "first world" project, operated particularly by prosperous western countries [28]. For example, in the 8-year period subsequent to 9/11, terrorist attacks on hotels all over the world more than doubled, from 30 to 62 , and the number of various countries which are influenced climbed up from 15 to 20 [30].

\section{CONCEPTUAL CLARIFICATIONS}

The word terrorism cannot be defined in a single definition and therefore, turn out to be one of the most disputed notions in the world. The explanation used might be as an outcome of the impact of the total numbers of attacks in a specific location. Nevertheless, calculating the exposure of macroeconomic and sectorial economic forms hugely relies on the chances of upcoming attacks and, relies on situation thinking [12]. Terrorism is a human forced calamity which intentionally targets at highest random demolition and which is projected to consistently evade obstructive measures. International Terrorism as stated by Li, Quan and Drew (2004) is "the methodical danger or usage of brutality over the national borders to achieve a political target or interact with a political message past terror, compulsion or terrorization of non-fighting people or the common public [22]."

Terrorists plan to have an influence on supply and demand in sequence to bring on the harmful results on prevailing economic systems. There are two major types of out-run which occurs: direct and indirect. The direct effects of terrorism incorporate the instant business outcomes as accomplished by individual firms.

The latter gathers and repeatedly turn to be identifiable only over time and incorporate long term alters like reduction in buyer demand; moves or interventions in value and supply chain; new policies, rules and regulations which have planned and unplanned effects; as well as alters in international relations and discernments that have an impact on trade and investment. These indirect effects constitute the imposing possible threat to the actions of firms. The effects of terrorism on the commerce and business as stated by Nitsch- Schumacher (2004) can be collected under 3 subjects: 
1. The atmosphere of suspicion that the terrorists bring up grow the business running rates. The almost uncertainty of the terrorists incidents renders the business plans pointless. The stress and load that fear conducts in the society alter the production and 1487 utilization motifs in the country and the shopping, transportation and tourism choices of people in specific, thereby effecting international trade.

2. The growth in the security rates opposed to fear enlarges handing out cycle and lifts marketing rates. On the basis of the absence of confidence which is aroused by the terrorism, the marketing of some goods turn out to be more dangerous which led to reduction in businesses.

3. Terror aims the goods and supply chain that provides the country reasonable benefit. As Ricardo put in his "comparative advantage theory", some countries manufacture some goods as a result of their competitive benefits. Terrorist activities aim these kinds of benefits.

\section{WHY BUSINESSES ARE THE TERRORISTS TARGET}

Businesses are used as aims by terrorists for a lot of uncommon reasons:

Some organizations are exceedingly noticeable targets; an attack on them is definite to allure the recognition of the media, broad segments of the population, and, as might be expected, the government hence supplies terrorists the exposure they search for.

$>$ A lot of organizations are gentle targets in the perception that it is not possible to avert potential terrorists from forthcoming or even intrude into the premises.

$>$ When organizations are attacked, fabrication and economic procedure is deranged. The organizations directly or indirectly influenced might be convinced to change the location to alternative region or countries. International organizations are less probable to commence direct overseas investments in that region. The financial situation inside the limits of the influenced country might exacerbate, directing to disappointment and by chance even rebels, creating it more likely that the declared targets of terrorists turn out to be more adequate and rational.

$>$ Some firms might be part of the jurisdiction and dominion on which the strength of the government that is confronted by terrorists reposes. The government might be the owner of the organizations or owned by the comrade of the government.

The more powerful the execution terrorists might anticipate their acts to have on businesses, the more probable it is that they will strike organizations. Organizations indicate appealing targets as they can be located nearly anywhere, and thus, are hard to safeguard. Furthermore, private organizations hate to allow and fund for their own defense. They have to recruit commercial security organizations and have to establish costly equipment lifting their costs of fabrication.

Business actors have to formulate tactics, which construct acts against businesses turn out to be less appealing to terrorists for the reason that their profitcost ratio has been decreased.

\section{TERRORISM AND ECONOMICS PERSPECTIVES}

Terrorism seems to have an impact on level of economic doings in a few fields [10]. To give an instance, after eruption of terrorism in Spain's Basque region in 1960s, per-capita GDP chopped down to nearly 10 percent when compared to an area of terrorism-free [11]. Regional business performance was enhanced remarkably through course of 19981999 respite but was once again rejected after respite came to an end. In per-capita GDP terms, Basque area was one of the few richest in Spain but significantly reduced after the thirty years of terrorist encounter. Terrorism enforced a negative reputational externality on the area with the foreign investors taking the side of optional locations which are terrorism-free [12].

As the organizations react towards terrorism, ideal decision-making is carried out by talented estimation which estimates the number of terrorists who would be in action in the time ahead. Economic statistics inside the rational-choice theory helps the estimations regarding the terrorist actions in the time-ahead [13]. Rational choice study is beneficial to research about tendency for terrorist actions; combining game theory with the arithmetic study can be a good instance.

Choice-theoretic model helps in improving the testable plans about the terrorist actions. Terrorists are supposed to be sane, economic mediators who find 
the maximum advantages and the minimum costs while functioning with the restricted incomes [14]. Restricted incomes are a significant restraint and display the degree to where terrorists have the economic and particular abilities, like the capability to create weapons of mass destruction. There is one more restraint which is the danger enforced by taking responsibility of terrorist actions. Terrorism is employed when the net estimated profits are more than the net estimated profits of other kinds of objection [15].

Economic study suggests how terrorism may be prevented, by decreasing the actual or the apparent profits to terrorist of hazardous events or by elevating costs related with undertaking terrorism. The employers and researches shall research on how to incline cost-benefit connection far from terrorists. Action can also be taken to lessen the resources which the terrorists possess. Talking about the real or probable issues of terrorists might be of some help. The attempts like these might have unplanned outcomes by encouraging the terrorists to plan the outbreaks on organizations and in countries who are unable to spend on the defensive methods. Planning which grows the cost or danger of any type of terrorist outbreak would force terrorists to select the alternative outbreak paths which have less cost [16].

Economic studies aid in opening up about the efficacy of attempts to overcome terrorism [17]. The organizations and administration experience choicetheoretic issue as they look to distribute rare resource to anticipating or reacting towards terrorism. Economic modeling could be beneficial to recognize numerous successful methods [18].

Terrorists have a habit to arise from the fields which are regarded as poverty, low economic development and ungoverned regions [19]. Poverty and underdevelopment usually portray the areas where administration cannot address daily necessities like making sure of sufficient set-up or regulations of law and thus are reluctant or powerless to banish the terrorists. Trade, FDI and the portfolio investment which encourages the economic development incline to generate an unintended negative impact on rise of terrorism [20]. MNEs can grow the sustainability and plan for the IB projects which address poverty and numerous social problems in developing the economies. The tactics like these give birth to good connections and aid in enhancing poor socio- economic indicators which might be related with rise of terrorist assemblies [21].

This paper concentrated on the most commonly used flip-flop in $0.12 \mu \mathrm{m}$ CMOS technologies. Comparisons are made with respect to power dissipation, delay, and area of the most popular designs. Different topology has different characteristics and benefits: the fastest one is $\mathrm{C}^{2} \mathrm{CMOS}$, its area, power dissipation, and delay are lesser than any other systems in this realm, while in the matters of power consumption the best ones are TSPC, P-FF, and SAFF. On the other hand, SDFF and HLFF are considered as the best topology as far as latency and clock skew are concerned. In general, considering the influence of the layout parasitic, simple and fundamental and conventional structures are much popular and widely accepted topology in micrometer systems.

\section{CONCLUSION}

Terrorism would enforce noticeable risks for the future. Terrorism threatens IB through direct and indirect impacts. Economics of terrorism takes the side of terrorists cost of defending from terrorist events is worth billions of dollars whereas as costs of the terrorism is in millions or lower. Globalization gives terrorists the powerful access to the strong technologies, enhanced staffing, more utilizable sources and aims of fury than before.

Business aims are comparatively more appealing to the terrorists as now the administration has increased security at public places. The highlight on homeland security in Europe and US might barely transmit the terrorists to softer aims which are the functioning places of numerous multinational organizations. To give an instance, poor security was a significant aspect in Mumbai, India outbreak. In Mumbai outbreak, Indian establishments were caught with surprise in a properly planned attack by commandos with the ideal weapons and technology. Commandos made use of digital technology to hold the prefunctioning investigation of aimed properties, negotiated Arabian Sea with the use of world ranking systems rapidly set the aims from the Google Earth Satellite pictures and made use of telephony and voice instead of Internet protocol so they can stay in communication continuously. Even though the countries are planned for the terrorist outbreak, they cannot always be planned for every kind of assault or secure every location. 
Organizations with the broad international actions shall highlight securing valued properties, specifically those which have too much possibility of being assaulted. Company actions which increase costs to terrorist reduce possibility of outbreak. Cooperative methods are most operative to stay secured from the terrorism. The organizations shall make join attempts with the administration and other organizations.

Current awareness and ecological scanning to identify and observe the upcoming risks are crucial to plan to match the growing hurdles. Practiced commencement and implementation of planning noticeably decreases the risk. Threat of terrorism could be later lessened by growing and executing supple emergency plans. The danger of terrorism cannot be diminished. The part of terrorism in IB should be comprehended properly.

\section{REFERENCES}

1) Abadie, Alberto and Javier Gardeazabal (2003), "The Economic Cost of Conflict: A Case Study of the Basque Country," American Economic Review, 93(1), 113-32.

2) Blomberg, S. Brock, Gregory D. Hess, and Athanasios Orphan ides (2004), "The Macroeconomic Consequences of Terrorism," Journal of Monetary Economics, 51(5), 1007-32.

3) Blomberg, S. Brock, Gregory D. Hess, and Akila Weerapana (2004), "Economic Conditions and Terrorism," European Journal of Political Economy, 20(2), 463-78.

4) Chen, Andrew H. and Thomas F. Siems (2004), "The Effects of Terrorism on Global Capital Markets," European Journal of Political Economy, 20(2), 249-66.

5) Collier, Paul, V. L. Elliott, Håvard Hegre, Anke Hoeffler, Marta Reynal-Querol, and Nicholas Sambanis (2003), Breaking the Conflict Trap: Civil War and Development Policy (Washington, DC: World Bank and Oxford University Press).

6) Collier, Paul and Anke Hoeffler (2004), "Greed and Grievance in Civil War," Oxford Economic Papers, 56(4), 563-95.

7) Collier, Paul and Nicholas Sambanis (2002), "Understanding Civil Wars: A New Agenda," Journal of Conflict Resolution, 46(1), 3-12.

8) Drakos, Konstantinos (2004), "Terrorism-Induced Structural Shifts in Financial Risk: Airline Stocks in the Aftermath of the September 11th Terror Attacks," European Journal of Political Economy, 20(2), 436-46.
9) Drakos, Konstantinos and Ali M. Kutan (2003), "Regional Effects of Terrorism on Tourism in Three Mediterranean Countries," Journal of Conflict Resolution, 47(5), 621-41.

10) Eckstein, Zvi and Daniel Tsiddon (2004), "Macroeconomic Consequences of Terror: Theory and the Case of Israel," Journal of Monetary Economics, 51(5), 971-1002.

11) Eldor, Rafi and Rafi Melnick (2004), "Financial Markets and Terrorism," European Journal of Political Economy, 20(2), 367-86.

12) Enders, Walter and Todd Sandler (1991), "Causality between Transnational Terrorism and Tourism: The Case of Spain," Terrorism, 14(1), 49-58.

13) Enders, Walter and Todd Sandler (1993), "The Effectiveness of Anti-Terrorism Policies: A Vector-Auto regression-Intervention Analysis," American Political Science Review, 87(4), 829-44.

14) Enders, Walter and Todd Sandler (1996), "Terrorism and Foreign Direct Investment in Spain and Greece," Kyklos, 49(3), 331-52.

15) Enders, Walter and Todd Sandler (2004), "What Do We Know About the Substitution Effect in transnational Terrorism?" in Andrew Silke (ed.), Research on Terrorism: Trends, Achievements and Failures (London: Frank Cass), 119-37.

16) Enders, Walter and Todd Sandler (2005), "Distribution of Transnational Terrorism among Countries by Income Class and Geography after 9/11," International Studies quarterly, 49(4), forthcoming.

17) Enders, Walter and Todd Sandler (2006), The Political Economy of Terrorism (Cambridge: Cambridge University Press), forthcoming.

18) Enders, Walter, Todd Sandler, and Gerald F. Parise (1992), "An Econometric Analysis of the Impact of Terrorism on Tourism," Kyklos, 45(4), 531-54.

19) Gupta, Sanjeev, Benedict Clements, Rina Bhattacharya, and Shamit Chakravorti (2004). "Fiscal Consequences of Armed Conflict and Terrorism in Low- and Middle-Income Countries," European Journal of Political Economy, 20(2), 403-21.

20) Kunreuther, Howard, Erwann Michel-Kerjan, and Beverly Porter (2003), “Assessing, Managing and Financing Extreme Events: Dealing with Terrorism," Working Paper 10179, National Bureau of Economic Research, Cambridge, MA. 
21) Li, Quan (2005), "Does Democracy Promote Transnational Terrorist Incidents?" Journal of Conflict Resolution, 49(2), 278-97.

22) Li, Quan and Drew Schaub (2004), "Economic Globalization and Transnational Terrorism," Journal of Conflict Resolution, 48(2), 230-58.

23) Mickolus, Edward F., Todd Sandler, Jean M. Murdock, and Peter Flemming (2004), International Terrorism: Attributes of Terrorist Events, 1968-2003 (ITERATE) (Dunn Loring, VA: Vinyard Software).

24) Murdoch, James C. and Todd Sandler (2002), "Economic Growth, Civil Wars, and Spatial Spillovers," Journal of Conflict Resolution, 46(1), 91-110.

25) Murdoch, James C. and Todd Sandler (2004), "Civil Wars and Economic Growth: Spatial Spillovers," American Journal of Political Science, 48(1), 138-51.

26) National Memorial Institute for the Prevention of Terrorism (2005). MIPT Terrorism Database [http://www.mipt.org], accessed May 19, 2005.
27) Nitsch, Volker and Dieter Schumacher (2004), "Terrorism and International Trade: An Empirical Investigation," European Journal of Political Economy, 20(2) 423-33.

28) Sandler, Todd (2003), "Collective Action and Transnational Terrorism," World Economy, 26(2), 779-802.

29) Sandler, Todd and Walter Enders (2004), “An Economic Perspective on Transnational Terrorism," European Journal of Political Economy, 20(2), 301-16.

30) Sloboda, Brian W. (2003), "Assessing the Effects of Terrorism on Tourism by the Use of Time Series Methods," Tourism Economics, 9(2), 17990.

31) Tavares, Jose (2004), "The Open Society Assesses its Enemies: Shocks, Disasters and Terrorist Attacks," Journal of Monetary Economics, 51(5), 1039-70.

32) United States Department of State Fact Sheet (2002), "Yemen: The Economic Cost of Terrorism,"

[http://www.state.gov/s/ct/rls/fs/2002/15028.htm] 